\title{
COMMUNITY STRUCTURE OF FISH AND ENVIRONMENTAL CHARACTERISTICS IN CISADEA RIVER, WEST JAVA, INDONESIA
}

\author{
Epa Paujiah*1, Dedy Duryadi Solihin ${ }^{2}$, Ridwan Affandi ${ }^{3}$
}

Received : October 10, 2019

Accepted : November 24, 2019

\section{DOI: 10.15575/biodjati.v4i2.6096}

${ }^{1}$ Biology Education Study Program, UIN Sunan Gunung Djati Bandung

Jl. A.H. Nasution No. 105, Cibiru, Bandung 40614, West Java, Indonesia ${ }^{2}$ Department of Biology, FMIPA IPB

Jl. Raya Dramaga Kampus IPB Dramaga Bogor 16680, West Java, Indonesia ${ }^{3}$ Department of Fisheries Resource Management, FPIK IPB

Jl. Raya Dramaga, Kampus IPB Dramaga Bogor 16680, West Java, Indonesia

e-mail:

*1epapaujiah@uinsgd.ac.id

${ }^{2}$ dduryadi@yahoo.com

${ }^{3}$ effendi_ridwan@yahoo.com

*Corresponding author
Abstract. Environmental characteristics can influence the distribution of animal communities including fish in aquatic habitats such as a river. The study of fish communities in Cisadea River aimed to learn the relation between the fish community structure and the environmental characteristics of the river itself. This research was conducted in Cisadea River, Cianjur Regency, West Java, Indonesia during dry season from July 2012 until February 2013. Samples of fish were caught using active fishing gear (Electrofishing Gear, spreading nets, scoop, lift net) and passive fishing gear (trap). The results showed that the quality of the physical chemistry of Cisadea waters was still in the normal range that could support fish life. The fish community in Cisadea River consisted of 11 orders, 26 families, 35 genera and 48 species. During the study, Rhyacichthys aspro $(19,85 \%)$ and Glyptothorax plathypogon $(20,15 \%)$ were the dominant species caught. The diversity index value (H') was 2.87 (middle category) with the dominance value of 0.09 (low category) and evenness value of 0.74 (high category). Moreover, community similarities according to the presence of species made the LC1 and LC2 locations in one group while the LC3 locations in a separate group.

Keywords: Cisadea river, community structure, diversity, environment, fish

\section{Citation}

Paujiah, E., Solihin, D. D. \& Affandi, R. (2019). Community Structure of Fish and Environtmental Characteristics in Cisadea River, West Java, Indonesia. Jurnal Biodjati, 4(2), 278-290

\section{INTRODUCTION}

Some fish species have an economic value and important roles in aquatic ecosystems. In addition, several fish species can be used as bioindicators of water pollution (Kopciuch et al., 2004). Freshwaters that cover 1\% of the earth's surface are inhabited by approximately 13.000 fish species (Lêvêque, 2008) that spread in the rivers and lakes.

The existence of fish communities in their habitat is affected by environmental factors such as biotic and abiotic factors in both of the space and time scale. Jackson et al. (2000) stateed that biotic and abiotic factors affect the structure of fish communities in rivers. Biotic factors affect the distribution of fish communities in river include predators and foods (Heithaus \& Dill, 2002). Whereas the abiotic factors (physics-chemical) mainly in river and estuary that determine fish distribution including height (Esselman et al., 2006), temperature (Ficke et al., 2007), salinity (Peterson \& Meador, 1994; Akin et al., 2005; Alcaraz et al., 2008), and turbidity (Akin et al., 2005). Furthermore Jansen et al. (1999) stat- 


\section{JURNAL BIDDJATI}

http://journal.uinsgd.ac.id/index.php/biodjati

ed that current velocity, water depth and substrate type are other main factors that determine the distribution of fish in river. Whether these environmental factors are optimal or not will certainly affect the life of fish. This shows that there is strong relationship between fish species and the environment as their habitat.

Geological history and geographic location are other abiotic factors that affect the distribution of fish communities. The rivers on the island of Java are included to the Eastern Sunda river group which is now becoming the Java Sea (Voris, 2000). In addition to its history and geographical location, fish distribution in river is affected by human activities. People around the river use these rivers as a source of water to fulfill their daily needs. River is usually used as a source of clean water for plantations, rice fields and fisheries. River is usually used as a source of clean water for plantations, rice fields, and fisheries. The Cisadea River in Cianjur Regency is used by the community as water sources for the needs of life. Other activities that take place around the river including fishing, logging, and industrial/ factory activities. The increasing of building construction and industrialization around the river can change the ecological conditions of waters such as physical and chemical quality. These changes can further affect the structure of the fish communities that live there (Dudgeon et al., 2006). In addition to those changes, if some activities that occur around the river are excessive and uncontrolled, it can threaten the ecosystem of river waters.

The condition of Cisadea River in West Java Province is affected by the activities of the community around the river which certainly affect the ecological conditions of the waters. These kinds of changes are not expected to occur in the waters of the Cisadea River. To anticipate this situation, it is necessary to manage biological resources in these waters so its ecological conditions of the waters remain stable. Therefore, the basic information about community structure, feeding habits and fish growth which correlated to the physical-chemical conditions of river waters is needed.

The studies on water conditions, community structure, food habits and growth of fish communities in the Cisadea River have not been fully reported. The study on the composition of freshwater fish species in Java has previously been reported by Robert (1993). In West Java, among 17 watersheds that flow towards the southern coast of Java (BPLHD, 2013), the studies of fish communities have been only conducted in a few rivers namely the Cisukawayana and Cibareno Rivers by Rachmatika (2003), and several rivers in Lebak and Bogor Regencies by Rachmatika \& Munim (2005). According to these researches, the study of fish communities in Cisadea River needs to be conducted to add information on the richness of river biological resources, especially those in West Java.

This study aimed to explore the distribution, trophic structure, and growth of fish that are correlated to the water conditions in Cisadea River, Cianjur Regency, West Java. The information regarding these aspects is expected to be the initial information for fish management and utilization in the future.

\section{MATERIALS AND METHODS}

\section{Study Area}

Sampling was carried out at stations that have been determined by Purposive Sampling based on certain considerations (Fachrul, 2008) as follows: the location of the waters where fish live such as ditches or leuwi and accessible locations. Sampling was conducted in three regions representing the upstream, middle and downstream sections with two sta- 


\section{JURNAL BIDDJATI}

http://journal.uinsgd.ac.id/index.php/biodjati

tions in each region. Water sampling followed the location of fish sampling. This was intended to observe the fish as well as the condition of the aquatic environment, thus the habitat characteristics of the fish obtained.

The research was conducted in Cisadea River, Cianjur Regency, West Java. The Cisadea River is the main river of the Cisadea River Basin, located in the Cianjur Regency, West Java Province. The river has a length of $44 \mathrm{~km}$ that crosses in 28 villages in 5 sub-districts (BPDAS, 2011). According to its topography, the Cisadea River is divided into three parts, the upstream part which is located in the villages of Mekarwangi (LC1.1 with coordinate point of $107^{\circ} 12^{\prime} 06.79^{\prime \prime} \mathrm{W} \quad 07^{\circ} 17^{\prime} 31.02^{\prime} \mathrm{S}$ ) and Cimaskara (LC1.2 with coordinate point of $107^{\circ} 12^{\prime} 01.77^{\prime} \mathrm{W} 07^{\circ} 18^{\prime} 14.15^{\prime}$ 'S), the middle part across Pamoyanan (LC2.1 with coordinate point of $107^{\circ} 12^{\prime} 01.77^{\prime} \mathrm{W} 07^{\circ} 18^{\prime} 50.13^{\prime}$ ' S) and Kalapa Nunggal villages (LC2.2 with coordinate point of $107^{\circ} 11^{\prime} 45.34^{\prime \prime} \mathrm{W}$ $07^{\circ} 19^{\prime} 44.67^{\prime}$ 'S) and the downstream part across Muara Cikadu (LC3.1 with coordinate point of $107^{\circ} 09^{\prime} 25.44^{\prime \prime} \mathrm{W} 07^{\circ} 25^{\prime} 25.44^{\prime \prime} \mathrm{S}$ and Saganten villages (LC3.2 with coordinate point of $107^{\circ} 07^{\prime} 45^{\prime \prime} \mathrm{W} 07^{\circ} 27^{\prime} 30$ 'S (Figure 1). Fish sampling were carried out for six month during dry season (July-Desember 2012). In each month, sampling was taken in the last week of month.

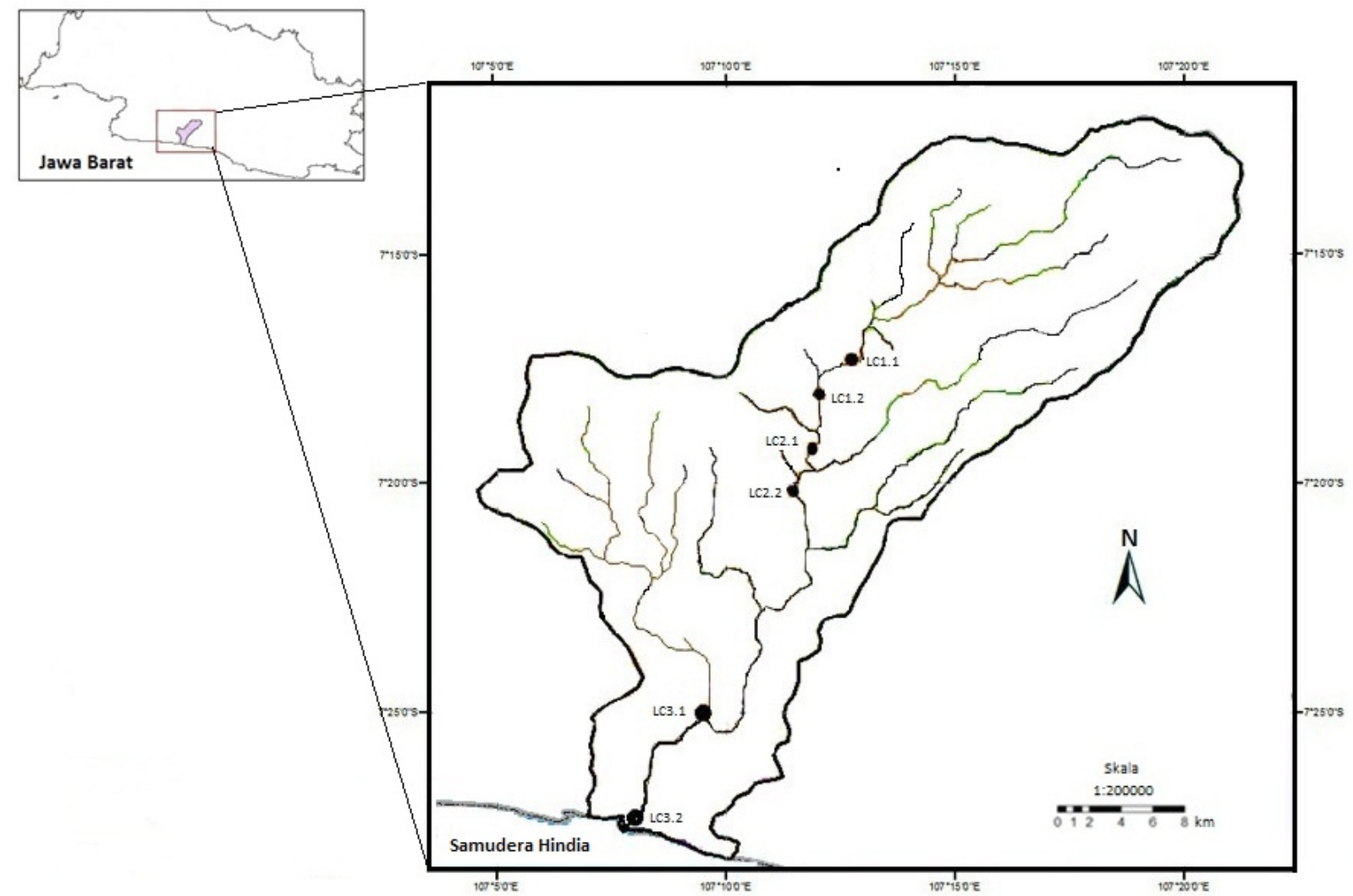

Figure 1. Sampling Site in the Cisadea River 


\section{JURNAL BIDDJATI}

http://journal.uinsgd.ac.id/index.php/biodjati

\section{Data Collection Techniques}

Water samples were obtained to measure the aquatic environmental parameters, as follows Table 1.

Fish were caught using active fishing gear (electrofishing, spreading nets, lift net, and scoop) and passive fishing gear (trap). The weight of caught fish was measured, documented and then preserved in $70 \%$ alcohol. Fish samples were identified and analyzed in the Biology Laboratory of the Faculty of Mathematics and Natural Sciences, and Biomacro Laboratory of FPIK IPB.

The composition of fish in Cisadea River was determined through identification based on its morphology (morphometric and meristic characters). Determination of morphometric and meristic components refered to Rachmatika (2003). Morphometric measurements of fish were conducted using a ruler with a precision of $1 \mathrm{~mm}$. Components for measurement of morphometric and meristic characters are presented in Tables 2, Table 3, Figure 4 and Figure 5. The data were then adjusted to the morphological characters based on the reference book. In general, the reference books used were Kottelat et al. (1993); Lim \& Ng (2000); Rachmatika (2003). In addition, the Gobiidae family refered to Allen (1991), Watson (1991) and Larson (2001), genus of Anguilla (Anguillidae) refered to Lin et al. (2005), the Carangidae family refered to Abdussamad et al. (2007), the genus of Microphis refered to Dawson (1984), and the genus of Kuhlia refered to Randall \& Randall (2001).

Table 1 . The aquatic environmental parameters

\begin{tabular}{llc}
\hline \multicolumn{1}{c}{ Parameters } & \multicolumn{1}{c}{ Metods and tool } & Location \\
\hline Water spread $(\mathrm{m} / \mathrm{s})$ & Current meter & Field \\
Substrate type & Visualisation & Field \\
River width $(\mathrm{m})$ & Meter tool & Field \\
Water depth $(\mathrm{cm})$ & Meter scale rope & Field \\
Temperature $\left({ }^{\circ} \mathrm{C}\right)$ & Thermometer & Field \\
Total suspensi solid $(\mathrm{mg} / \mathrm{L})$ & Whatmen & Laboratory \\
Turbidity $(\mathrm{NTU})$ & Turbidimeter & Laboratory \\
Salinity $(\mathrm{ppt})$ & Rephractometer & Field \\
Dissolved Oxygen $(\mathrm{mg} / \mathrm{L})$ & DO meter & Field \\
pH (unit) & pH meter & Field \\
Alkalinity $(\mathrm{mg} / \mathrm{L})$ & Titration & Laboratory \\
Presentation of vegetation cover $(\%)$ & Visualisation & Field \\
Surrounding Condition & Visualisation & Field \\
\hline
\end{tabular}

\section{Data Analysis}

Data on the aquatic environment observation at each location were analyzed by comparing observational data with optimum standards of water quality for fish life. The quality standard refers to various existing li- braries. Analysis of the fish community structure was conducted using the Primer program (Plymouth Routines in Multivariate Ecological Research) version 5 (Somerfield, 2008). This program was used to analyze the Shannon-Wiener diversity index, Simpson domi- 


\section{JURNAL BIDDJATI}

http://journal.uinsgd.ac.id/index.php/biodjati

nance index, and Pielou's evenness index. The community similarity analysis was carried out based on the Bray-Curtis index. Analysis of the relationship between the water physical-chemical parameters with fish distribution was conducted to find out the environmental parameters that affected the distribution of fish in each observation location. These relationships were analyzed using Canonical Correspondence Analysis (CCA) through the R program version 2.15.2 (Quinn \& Keough, 2002).

\section{RESULTS AND DISCUSSION}

\section{Environmental Characteristics of the Cis- adea River}

The results of the water conditions analysis on the physical, chemical and biological components are presented in Table 2. Based on Table 2, the LC3.1 had the highest current speed while the LC3.2 had the lowest current speed. Thus based on the river region, the current speed did not increase from upstream to downstream.

Table 2. The environmental parameters range values of the Cisadea River, Cianjur Regency, West Java

\begin{tabular}{|c|c|c|c|c|c|c|c|}
\hline \multirow{2}{*}{ Parameter } & \multicolumn{6}{|c|}{ Locations } & \multirow{2}{*}{$\begin{array}{l}\text { Optimum } \\
\text { range }\end{array}$} \\
\hline & $\mathrm{LC} 1.1$ & $\mathrm{LC} 1.2$ & $\mathrm{LC} 2.1$ & $\mathrm{LC} 2.2$ & LC3.1 & $\mathrm{LC} 3.2$ & \\
\hline River Width (m) & 36 & 24 & 16 & 26 & 57 & 115 & - \\
\hline $\mathrm{WD}(\mathrm{cm})$ & $\begin{array}{c}25.33-37 \\
(31.33)\end{array}$ & $\begin{array}{c}21.33-40 \\
(29.33)\end{array}$ & $\begin{array}{c}32.67-37 \\
(34.84)\end{array}$ & $\begin{array}{c}20-38 \\
(26.11)\end{array}$ & $\begin{array}{c}11-31.67 \\
(23.11)\end{array}$ & $\begin{array}{c}53.67-89.67 \\
(69.45)\end{array}$ & - \\
\hline $\begin{array}{l}\text { Current Speed } \\
(\mathrm{m} / \mathrm{s})\end{array}$ & $\begin{array}{c}0.56-1.85 \\
(1.28)\end{array}$ & $\begin{array}{c}0.59-2.09 \\
(1.56)\end{array}$ & $\begin{array}{c}0.41-2.13 \\
(1.46)\end{array}$ & $\begin{array}{c}0.41-2.63 \\
(1.69)\end{array}$ & $\begin{array}{l}0.11-3.70 \\
(2.03)\end{array}$ & $\begin{array}{l}0.06-0.18 \\
(0.12)\end{array}$ & - \\
\hline $\begin{array}{c}\text { Temperature } \\
\left({ }^{\circ} \mathrm{C}\right)\end{array}$ & $\begin{array}{l}19-25 \\
(20.8)\end{array}$ & $\begin{array}{l}19-25 \\
(21.8)\end{array}$ & $\begin{array}{l}20-26 \\
(22.5)\end{array}$ & $\begin{array}{c}21-26.5 \\
(22)\end{array}$ & $\begin{array}{l}23-32 \\
(26.3)\end{array}$ & $\begin{array}{c}21.5-28 \\
(24.8)\end{array}$ & $24-26[4]$ \\
\hline $\begin{array}{l}\text { Turbidity } \\
\text { (NTU) }\end{array}$ & $\begin{array}{c}1.1-3.8 \\
(2.4)\end{array}$ & $\begin{array}{l}1.7-3.4 \\
(2.43)\end{array}$ & $\begin{array}{l}1.6-2.6 \\
(2.00)\end{array}$ & $\begin{array}{c}1.9-4.2 \\
(2.83)\end{array}$ & $\begin{array}{l}1.8-8 \\
(5.47)\end{array}$ & $1.5-5.8(3.47)$ & $1-10[5]$ \\
\hline $\mathrm{TSS}(\mathrm{mg} / \mathrm{L})$ & $\begin{array}{c}3 \times 10^{-3}- \\
0.1(0.05)\end{array}$ & $\begin{array}{c}7 \times 10^{-3}-0.1 \\
(0.05)\end{array}$ & $\begin{array}{c}4 \times 10^{-4}-0.1 \\
(0.05)\end{array}$ & $\begin{array}{c}2 \times 10^{-4}- \\
0.1(0.05)\end{array}$ & $\begin{array}{c}6 \times 10^{-3}-0.2 \\
(0.10)\end{array}$ & $\begin{array}{c}2 \times 10^{-3}-0.3 \\
(0.15)\end{array}$ & $<80[3]$ \\
\hline $\mathrm{DO}(\mathrm{gr} / \mathrm{L})$ & $5.6(5.6)$ & $6(6.00)$ & $\begin{array}{l}6-6.4 \\
(6.20)\end{array}$ & $6.4(6.40)$ & $\begin{array}{l}5.6-6 \\
(5.80)\end{array}$ & $5.6-6(5.80)$ & $>5[7]$ \\
\hline $\mathrm{pH}$ (Unit) & $\begin{array}{c}6.8-7.6 \\
(7.27)\end{array}$ & $\begin{array}{c}7.2-8.9 \\
(7.9)\end{array}$ & $\begin{array}{l}7.1-10 \\
(8.27)\end{array}$ & $\begin{array}{c}7.6-10.2 \\
(8.7)\end{array}$ & $\begin{array}{c}5.8-7.5 \\
(6.8)\end{array}$ & $6.2-8.2(7.4)$ & $6-9[1]$ \\
\hline Alkalinity (mL) & $\begin{array}{c}1.2-1.6 \\
(1.33)\end{array}$ & $\begin{array}{c}1.2-1.6 \\
(1.43)\end{array}$ & $\begin{array}{l}1.3-1.8 \\
(1.55)\end{array}$ & $\begin{array}{c}1.2-2.0 \\
(1.57)\end{array}$ & $\begin{array}{l}1.9-2.9 \\
(2.33)\end{array}$ & $2.1-3.0(2.53)$ & $<48[6]$ \\
\hline Salinity (ppt) & 0 & 0 & 0 & 0 & 0 & $0.2-0.5(0.23)$ & $<5[2]$ \\
\hline Substrate type & $\mathrm{S}, \mathrm{G}$ & $\mathrm{S}, \mathrm{G}, \mathrm{Sa}$ & $\mathrm{S}, \mathrm{G}, \mathrm{Sa}$ & $\mathrm{S}, \mathrm{G}, \mathrm{Sa}$ & $\mathrm{G}, \mathrm{Sa}$ & $\mathrm{Sa}, \mathrm{M}, \mathrm{R}$ & - \\
\hline $\begin{array}{l}\text { Vegetation } \\
\text { cover }\end{array}$ & $10 \%$ & $15 \%$ & $10 \%$ & $5 \%$ & $10 \%$ & $0 \%$ & - \\
\hline $\begin{array}{l}\text { Surrounding } \\
\text { Condition }\end{array}$ & $1 \mathrm{c}, 1 \mathrm{e}$ & $1 \mathrm{c}, 1 \mathrm{f}$ & $1 \mathrm{c}, 1 \mathrm{~d}, 1 \mathrm{f}$ & $\begin{array}{l}1 \mathrm{a}, 1 \mathrm{c}, \\
1 \mathrm{~d}, 1 \mathrm{f}\end{array}$ & $\begin{array}{c}1 \mathrm{a}, 1 \mathrm{~b}, 1 \mathrm{c}, \\
1 \mathrm{~d}, 1 \mathrm{f}\end{array}$ & $1 \mathrm{a}, 1 \mathrm{~b}$ & - \\
\hline
\end{tabular}

Note: TSS: Total suspended solids, DO: Dissolved oxygen, Substrate type (S: Stone, G: Gravel, Sa: Sand, M: Mud, R: rock), K. about: Conditions around (1a: Settlements, 1b: MCK, 1c: Agriculture, 1d: Plantation, 1e: Industrial households, 1f: sand mining), [1] Tucker \& D'Abramo (2008) [2] Khlebovich \& Aladin (2010), [3] Tarigan \& Edward (2003), [4] Buckel et al. (1995), [5] Carter et al. (2010), [6] Shahnawaz et al. (2010), [7] Salmin (2005). 


\section{JURNAL BIDDJATI}

http://journal.uinsgd.ac.id/index.php/biodjati

The highest temperature found in the location of LC3.1 while the lowest found in the LC1.1 location. So the upstream temperature was lower than the downstream temperature. The LC3.1 location was the location with the highest turbidity while LC2.1 location had the lowest turbidity. Meaning that compared to other locations, the waters at location LC2.1 were clean while water at location LC3.1 was more turbid. The highest total suspended solids were found in LC3.2 location while the lowest were found in LC1 and LC2.1 locations. Thus the amount of dissolved solids is going higher along with the downstream flow. Biotic and abiotic factors are important factors that affect the waters and organisms living there. There are differences in the current speed in each region of the river. The current velocity in the LC1, LC2 and LC3.1 (1.28-2.03) is included as the category of fast-flowing rivers $(>1$ $\mathrm{m} / \mathrm{s}$ ) while the LC3.2 location is slow-flowing river $(<0.5 \mathrm{~m} / \mathrm{s})$ (Rachmatika, 2003). Dettinger \& Diaz (2000) stated that the speed of river currents is affected by river structure and other factors such as season and altitude.

Dissolved oxygen at each location was found relatively similar. The highest $\mathrm{pH}$ of river water was found at LC2.2 while the smallest $\mathrm{pH}$ value was found at LC3.1. The dissolved oxygen (5.6-6.4 $\mathrm{mg} / \mathrm{L}$ ) and $\mathrm{pH}$ (7.27-8.7) of the Cisadea River water are still in the normal range that can be tolerated by aquatic organisms. The ranges of dissolved oxygen content and water $\mathrm{pH}$ that can support the life of organisms are $>5 \mathrm{mg} / \mathrm{L}$ (Salmin, 2005) and 6-9 (Tucker \& D'Abramo, 2008) respectively. Kramer (1987) stated that there is a relationship between dissolved oxygen content and fish behavior. The dissolved oxygen is able to change fish activities and fish habitat. The range of water salinity found during the study (0-0.23 ppt) can be categorized as a type of freshwa- ter $(<5$ ppm) (Khlebovich \& Aladin, 2010). The temperature range of Cisadea River waters during the study $\left(19-32^{\circ} \mathrm{C}\right)$ was still in the normal range. Buckel et al. (1995) stated that the range of temperatures that can support the growth rate and fish consumption in the waters is $21-30^{\circ} \mathrm{C}$.

The highest value of alkalinity was found in the LC3.2 location while the lowest alkalinity found in LC1.1 location. Based on those values, the alkalinity is higher along with the downstream. The alkalinity range value of the river was not too high (0-0.5 ppt). The LC3.2 is the location that had the highest salinity $(2.3 \mathrm{ppt})$ while the other location has a salinity value of $0 \mathrm{ppt}$. Therefore, waters containing salinity are only found in the downstream of the river (LC3.2 location).

The value of total suspended solids (0.05-0.15 mg/L), turbidity (1.1-8 NTU), and alkalinity (1.33-2.53 mg/L) of Cisadea River were still in the normal range. The value of total suspended solids, water turbidity and alkalinity that can support the life of the organism are $<80 \mathrm{mg} / \mathrm{L}$ (Tarigan \& Edward, 2003), 0-40 NTU (Carter et al., 2010) and $<48$ $\mathrm{mg} / \mathrm{L}$ (Shahnawaz et al., 2010) respectively.

The depth of water from the upstream to downstream areas found different. The amount of water discharge in the upstream area comes from the combination of river and sea. The depth of the river water is affected by rainfall. During the dry season, the water discharge that comes to the river body is small, while in the rainy season the water discharge is quite big. This causes a difference in river water depth between the rainy season and the dry season. Sulistiyarto et al. (2007) reported that the season is one of the factors affecting the composition and abundance of fish species in the Rungan River, Central Kalimantan.

According to the type of substrate, the observation location was divided into 


\section{JURNAL BIDDJATI}

http://journal.uinsgd.ac.id/index.php/biodjati

four groups. LC1.1 were the type of location with rock and gravel substrate, while LC1.2, LC2.1 and LC2.2 locations were rock, gravel and sand substrate types. LC3.1 is a type of location that consisted of gravel and sand substrate while LC3.2 location consists of sand and mud substrate. Based on the type of substrate, sand is the dominant type of substrate found in the Cisadea River.

The environmental condition of the waters can certainly affect fish distribution, especially in the flowing waters such rivers. Some fish species in rivers have specific aquatic environmental characteristics so their distribution is quite limited. The species of Tor soro can only be found in waters that have high dissolved oxygen content, clear waters, moderate to heavy flow velocity, the bottom waters in the form of rocks and gravel, and in the river are in the environment of forests or canopy with high closure. These characteristics can be found in the upstream of the river. In the other types of Tor fish such as Tor tambroides, Haryono \& Subagja (2008) reported that the fish can be found in the upper reaches of the river with habitat characteristics of substrate consisting of gravel and sand, the bottom of the water is generally in the form of rocks withclear water, slow to heavy water flow, and the river environment is mostly primary forest.

\section{Fish Communities Structure}

The structure of the fish communities studied consisted of the following parameters; species composition and its distribution, diversity index, evenness index, dominance index, and community similarity index.

\section{Species Composition}

Fish species obtained were classified according to family and genus. The composition of fish species found consisted of 48 species, 35 genera, 26 families and 11 orders. The dis- tribution of fish species in the Cisadea River was varied. Barbodes binotatus and Poecilia reticulata were fish species that were widely distributed. These fishes could be found both in the upstream and downstream areas. Besides these fishes, there are some fishes found at four locations observation, namely Sicyopterus. cf. cyanocephalus, Sicyopterus ouwensi, Tor soro, Glyptothorax plathypogon and Rhyacihthys aspro. Apart from these fishes, other fish species have a fairly narrow distribution that can be found in two locations or only in one location.

The total number of individuals found at the six locations was 666 inividuals. Based on the river area, it was found that the downstream area had more species composition than the middle and upstream. The most common Order found was the siluriformes, and the largest family found was Gobiidae. Based on species, R. aspro (132 individuals or $19.85 \%$ ) and G. plathypogon (134 individuals or $20.15 \%$ ) were the two species that are most commonly found. The fish caught was in the size of 65-85 $\mathrm{mm}$ for $R$. aspro and 64-69 mm for G. plathypogon.

\section{Index of Diversity, Evenness and Dominance of Fish}

The results of the analysis are presented in Table 3. The value of diversity index $\left(\mathrm{H}^{\prime}\right)$ was found high at the LC3.2 location $(4,10)$. The dominance index value in the six study locations showed a low value (not close to number 1) with high spreading species (close to number 1). Overall the analysis, the diversity index value was 2.87 with a dominance of 0.09 and evenness of 0.74 .

\section{Similarity Index}

The results of similarity index analysis reveal the similarities and differences between one community and other communities. This 


\section{JURNAL BIDDJATI}

http://journal.uinsgd.ac.id/index.php/biodjati

community similarity index was analyzed based on the presence of fish species in the six observation locations. The results of the analysis are presented in Table 4 and Figure 2.

Based on the results of the Bray-Curtis community similarity index calculation
(Table 4), the six observation locations could be grouped into two community groups. The LC1 (upstream) and LC2 (middle) locations were grouped into one community, while the LC3 (downstream) location was a separate community group (Figure 2).

Table 3. Diversity index values $\left(H^{\prime}\right)$, dominance $(\lambda)$ and evenness $\left(J^{\prime}\right)$ of fish communities in each observation location

\begin{tabular}{cccccccccc}
\hline \multirow{2}{*}{ Index } & \multicolumn{3}{c}{ Upstream } & \multicolumn{3}{c}{ Middle } & \multicolumn{3}{c}{ Downstream } \\
\cline { 2 - 11 } & LC1.1 & LC1.2 & $\overline{\mathrm{x}}$ & LC2.1 & LC2.2 & $\overline{\mathrm{x}}$ & LC3.1 & LC3.2 & $\overline{\mathrm{x}}$ \\
\hline $\mathrm{H}^{\prime}$ & 1.95 & 2.03 & 1.99 & 2.23 & 2.06 & 2.15 & 2.5 & 4.10 & 3.30 \\
$\lambda$ & 0.34 & 0.32 & 0.33 & 0.27 & 0.33 & 0.30 & 0.26 & 0.09 & 0.18 \\
$\mathrm{~J}$ & 0.69 & 0.68 & 0.69 & 0.74 & 0.62 & 0.68 & 0.67 & 0.81 & 0.74 \\
\hline
\end{tabular}

Table 4. Matrix of similarity values of fish communities in the six study locations based on the Bray-Curtis index (\%)

\begin{tabular}{ccccccc}
\hline Location & LC1.1 & LC1.2 & LC2.1 & LC2.2 & LC3.1 & LC3.2 \\
\hline LC1.1 & & & & & & \\
LC1.2 & 88.90 & & & & & \\
LC2.1 & 89.07 & 87.28 & & & & \\
LC2.2 & 78.71 & 85.97 & 80.71 & & & \\
LC3.1 & 13.45 & 12.70 & 13.37 & 15.64 & & \\
LC3.2 & 0 & 0 & 0 & 0 & 16.61 & \\
\hline
\end{tabular}

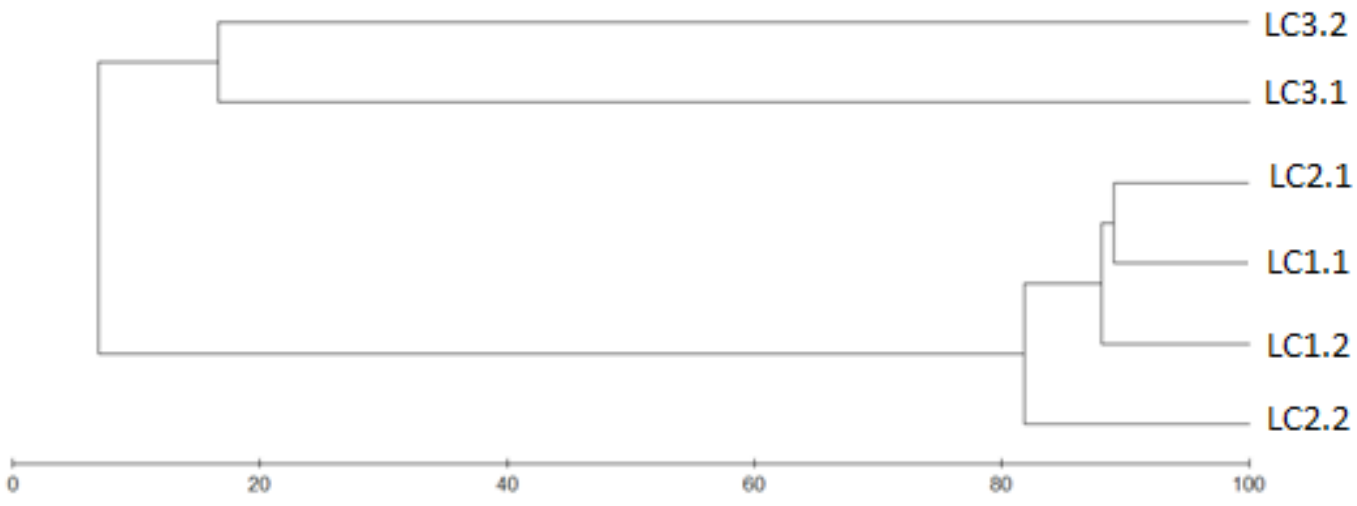

Figure 2. Dendrogram of community level similarity based on the presence of fish species in six study sites.

Compared to other rivers that end its flow to the south coast of West Java, the richness of fish species (48 species) in Cisadea River is in the high category. Rachmatika (2003) reported among all observed rivers in Mount Halimun National Park, West Java Paujiah et al. there are two rivers that flowing to the south coast of West Java, namely Cisukawayana and Cibareno Rivers. Fish species found in the Cisukawayana River consisted of 18 species with 8 families while the fish found in the Cibareno River consists of 29 species 


\section{JURNAL BIDDJATI}

http://journal.uinsgd.ac.id/index.php/biodjati

with 18 families. In 2005, Rachmatika and Munim reported the number of fish species in several rivers in the Lebak and Bogor Regencies. The results showed that the river was inhabited by 15 species of fish from 9 families. According to these three results of the study, there are 10 same species found during this research, namely Glyptothorax plathypogon, Barbodes binotatus, Poecilia reticulata, Anguilla marmorata, Microphis brachyurus, Liza macrolepis, Rhyacichthys aspro, Eleotris melanosoma, Sicyopterus cf. cyanocephalus and Kuhlia marginata. This shows that the 10 species have a considerable tolerance to the conditions of the waters of West Java; therefore it has a wide distribution. Robert (1993) reported that the species has a fairly wide distribution in Java Island.

Based on the fishing catch result, there are differences in the number of individual fish in each location. The highest number of catches was found at the LC3.2, both based on individuals or species. The lowest number of individuals found was in the upstream and the lowest species found was in the downstream of the river. In general, the number of individuals and species from upstream to downstream was getting higher. High or low of the number fish in a place can be affected by human activity (fisherman), environmental conditions of the waters and diverse habitats (Angel \& Ojeda, 2001; Yeager et al., 2011).

The fishing activities proceed by the residents using potassium (Potassium cyanide) are often occur around the upstream and middle of the river. This certainly can disturb the presence of organisms inside the waters. Yuningsih (2012) stated that Potassium cyanide is a toxic chemical compound that is quickly active inside the body and can cause death within minutes (acute).

Aquatic environmental conditions such as the characteristics of the substrate types in each river area appear to be related to the presence of fish. In the flowing waters such as rivers, the substrate is a habitat that functions as a fish place to live. This can be seen from many fish that were caught near rocks and sand. In addition to substrate type, current velocity (Jansen et al., 1999), and salinity are also limiting factors for the distribution of fish communities (Akin et al., 2005). This is in accordance with the result of this study where the locations that have high current velocity, low salinity and shallow waters (locations LC1, LC2 and LC3.1) were inhabited by a low number of species. Whereas locations that have high salinity, high depth, and low current velocity variations (location LC3.2) were inhabited by high number of species.

The diverse habitats found in the LC3.2 location, which include mangrove and coral habitats. One of the functions of mangroves as a food provider and protection against predators (Nagelkerken et al., 2008) makes mangrove as one of the most suitable habitats for fish. Therefore the presence of mangrove habitat in the LC3.2 location can determine the abundance of fish. In addition, the presence of coral in that location is a complementary habitat for fish that use coral as their habitat. The existence of a variety of habitat in these locations will certainly be lived by a variety of species as well.

$G$. palthypogon and $R$. aspro are two species that were caught compared to other species. Both of these species were fish that the distribution found in the upstream and middle of the river. Watanabe (1972), Kottelat et al. (1993), Keith (2002) and Rachmatika (2003) stated that these fish can be found in parts of rivers that have heavy currents and types of substrates consisting of gravel and rocks. Water characteristics and substrate types in the Cisadea River that are relatively similar make the fish distributed quite dominantly in 


\section{JURNAL BIDDJATI}

http://journal.uinsgd.ac.id/index.php/biodjati

the upstream and middle of the river.

The structure of fish communities in river waters is affected by abiotic and biotic environmental components. As shown by the CCA analysis (Figure 3), the depth, total suspended solids, salinity, and alkalinity strongly influenced the fish abundance.

The depth factor is one of the important environmental factors that affect the distribution of fish in the Cisadea River.
The result of the study by Esselman \& Allan (2010) showed that depth is one of the factors that greatly affect the distribution of fish in river waters in Southeast Mesoamerica. The depth of water influences the diversity of fish. In lakes, the diversity of fish tends to increase with increasing depth of water (Raharadjo et al., 2011).

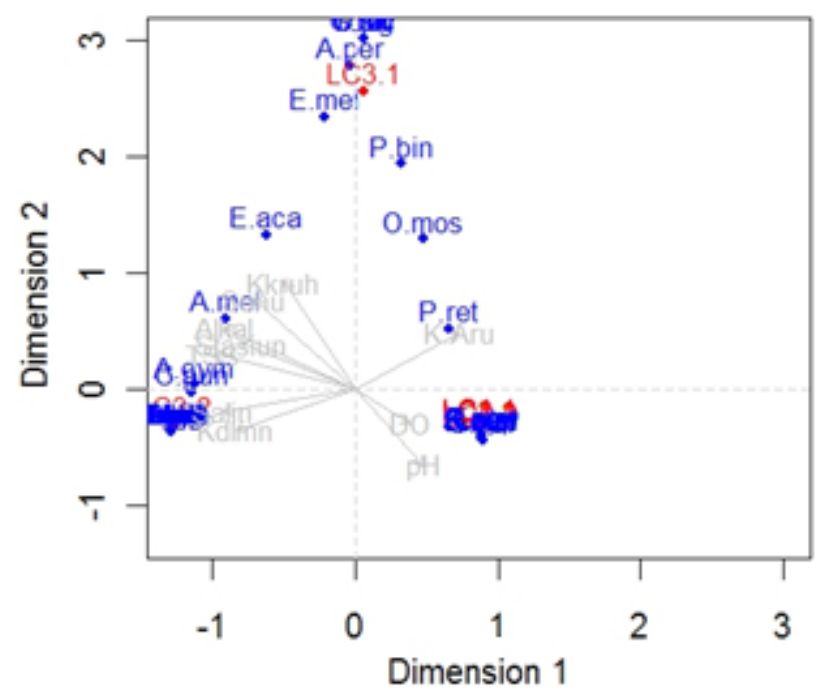

Figure 3 Results of CCA applications for the physical-chemical parameters of the waters and their effects on fish abundance in the Cisadea River.

A high total suspended solid content will increase the turbidity. The high turbidity of water is used by fish as protection from predators and to find food. The variation or degree of turbidity between the sea and estuary is an advantage for juveniles to migrate from the sea to freshwater or contrarily (Akin et al., 2005).

Salinity is another factor that affects the presence of fish. From the observations, it appeared that the more salinity variation in the waters, the higher the number of species. The salinity variation in the downstream area influences the distribution of fish as downstream is an encounter area between freshwater and sea. Therefore the species in it is Paujiah et al. a mixture of the two species of these waters.

Alkalinity is an important component in maintaining the $\mathrm{pH}$ balance of waters. The higher the value of alkalinity, the buffer ability of waters is higher. This makes the $\mathrm{pH}$ fluctuation gets lower. The high or low $\mathrm{pH}$ fluctuations will affect organisms in it such as fish and abundance of fish in waters (Higgins \& Wilde, 2005).

The physical and chemical parameters of waters in the Casadea River were still in good condition to support fish life. Physical-chemical parameters that affect the abundance of fish species are depth, total suspended solids, salinity and alkalinity. 


\section{JURNAL BIDDJATI}

http://journal.uinsgd.ac.id/index.php/biodjati

The fish community in the waters of the Cisadea River consists of 48 species, 35 genera, 26 families and 11 orders which were dominated by 2 species, namely $R$. aspro and G. plathypogon. The diversity of species was getting higher towards downstream. The upstream and middle river areas were dominated by boboso fish ( $R$. aspro) and Kehkel (G. plathypogon) while in the downstream areas were dominated by baronang fish (Siganus vemiculatus) and snapper (Lutjanus spp.).

\section{ACKNOWLEDGEMENTS}

We thanks those who helped us carry out the sampling: Aris, Ali, and fishermen who helped sampling with the sampling survey. We thanks to Mr. Haryono for revision of this document and for the anonymous reviewers that helped us improve this article.

\section{REFERENCES}

Abdussamad, E. M., Prathibha, R., Mohammed, O. M. M. J. H. (2007). A Field Identification Key for 20 Genera of Family Carangidae. Journal of the Marine Biological Association of India, 49(2), $141-147$.

Akin, S., Buhan, E., Winemiller, K. O. \& Yilmaz, H. (2005). Fish Assemblage Structur of Koycegiz Lagoon-Estuary, Turkey: Spatial and Temporal Distribution Pattern in Relation to Environmental Variation. Estuarine, Coastal and Shelf Sciences, 64, 671-684.

Alcaraz, C., Bisazza, A. \& Garc1'a-Berthou, E. (2008). Salinity Mediates the Competitive Interactions Between Invasive Mosquitofish and an Endangered Fish. Oecologia, 155, 205-213.

Allen, G. R. (1991). Field Guide to The Freshwater Fishes of New Guinea. Christens- es Research Institute: Papua New Guinea. 268 p.

Angel, A. \& Ojeda, F. P. (2001). Structure and Trophic Organization of Subtidal Fish Assemblages on the Northern Chilean Coast: the Effect of Habitat Complexity. Marine Ecology Progress Series, 217, 81-91.

Badan Pengelolaan Daerah Aliran Sungai [BPDAS]. (2011). RAPDS Cisadea. BPDAS Citarum-Ciliwung Bogor.

BPLHD Jawa Barat. (2010). Status Mutu Sungai di 7 DAS Provisi Jawa Barat. World Wide Web Electronic Publication [Internet]. [diacu pada tanggal 8 Mei 2013]. Tersedia dari: psda.jabarprov.go.id. Buckel, J. A., Steinberg, N. D. \& Conover, D. O. (1995). Effects of Temperature, Salinity and Fish Size on Growth and Consumption of Juvenile Bluefish. Journal of Fish Biology, 47, 696-706.

Carter, M. W., Shoup, D. E., Dettmers, J. M. \& Wahl, D. A. (2010). Effects of Turbidity and Cover on Prey Selectivity of Adult Smallmouth Bass. Transactions of the American Fisheries Society, 139, 353-361.

Dawson, C. E. (1984). Revision of the Genus Microphis kaup (Pisces: Syngnathidae). Bulletin of Marine Science, 35(2), 117181.

Dettinger, M. D. \& Diaz, H. F. (2000). Global Characteristics of Stream Flow Seasonality and Variability. Journal of Hydrometeorology, 1, 289-310.

Dudgeon, D., Arthington, A. H., Gessner, M. O., Zen-Ichiro, K., Knowler, D. J., Lêvêque, C., Naiman, R. J., Prieur-Richard, A. H., Soto, D., Stiassny, M. L. J. \& Sullivan, C. A. (2006). Freshwater Biodiversity: Importance, Threats, Status and Conservation Challenges. Biological Reviews, 81, 163-182. 


\section{JURNAL BIDDJATI}

http://journal.uinsgd.ac.id/index.php/biodjati

Esselman, P. C. \& Allan, J. D. (2010). Relative Influences of Catchment and Reach Scale Abiotic Factors on Freshwater Fish Communities in Rivers of Northeastern Mesoamerica. Ecology of Freshwater Fish, 19, 439-454.

Fachrul, M. F. (2008). Metode Sampling Bioekologi. Jakarta: Bumi Aksara.

Ficke, A. D., Myrick, C. A, Hansen, L. J. (2007). Potential Impacts of Global Climate Change on Freshwater Fisheries. Reviews in Fish Biology and Fisheries, 17, 581-613.

Haryono \& Subagja, J. (2008). Populasi dan Habitat Ikan Tambra, Tor tambroides (Bleeker, 1854) di Perairan Kawasan Pegunungan Muller Kalimantan Tengah. Biodiversitas, 9(4), 306-309.

Heithaus, M. R. \& Dill, L. M. (2002). Food Availability and Tiger Shark Predation Risk Influence Bottlenose Dolphin Habitat Use. Ecology, 83(2), 480-491.

Higgins, C. L. \& Wilde, G. R. (2005). The Role of Salinity in Structuring Fsh Assemblages in a Prairie Stream System. Hydrobiologia, 549, 197-203.

Jansen, W., Kappus, B., Böhmer, J. \& Beiter, T. (1999). Fish Communities and Migrations in the Vicinity of Fishways in a Regulated River (Enz, Vaden-Württemberg, Germany). Limnologica, 29, 425-435.

Jackson, D. A., Peres-Neto, P. R. \& Olden, J. D. (2001). What Controls Who is Where in Freshwater Fish Communities-the Roles of Biotic, Abiotic and Spatial Factors. Canadian Journal of Fisheries and Aquatic Sciences, 58,157-170.

Khlebovich, V. V. \& Aladin, N. V. (2010). The Salinity Factor in Animal Life. Herald of the Russian Academy of Sciences, 80(3), 299-304.

Kopciuch, R. G., Berecka, B., Bartoszewicz. J. \& Buszewski, B. (2004). Some Con- siderations about Bioindicators in Environmental Monitoring. Environmental, 13, 453-462.

Kottelat, M., Whitten, A. J., Kartikasari, S. N. \& Wirjoatodjo, S. (1993). Freshwater Fishes of Western Indonesia and Sulawesi. Hongkong: Periplus Editions.

Kramer, D. L. (1987). Dissolved Oxygen and Fish Behavior Environmental. Biology of Fishes, 18(2), 81-92.

Larson, H. K. (2001). A Revision of the Gobiid fish genus Mugilogobius (Teleostei: Gobioidei) and its Systematic Placement. Records of the Western Australian Museum, Supplement no. 62.

Lêvêque, C., Oberdorff, T., Paugy, D., Stiassny, M. L. J. \& Tedesco, P. A. (2008). Global Diversity of Fish (Pisces) in Freshwater. Hydrobiologia, 595, 545-567.

Lin, Y. S., Tzeng, C. S. \& Hwang, J. K. (2005). Reassessment of Morphological Characteristics in Freshwater Eels (Genus Anguilla, Anguillidae) Shows Congruence with Molecular Phylogeny Estimates. Zoologica Scripta, 34, 225-234.

Lim, K. K. P. \& Ng, P. K. L. (2000). A Guide to The Freshwater Fishes of Singapore. Singapore: Singapore Science Centre.

Nagelkerken, I., Blaber, S. J. M., Bouillon, S., Green, P., Haywood, M., Kirton, L. G., Meynecke, J. O., Pawlik, J. \& Penrose, H. M. (2008). The Habitat Function of Mangroves for Terrestrial and Marine Fauna: A review. Aquatic Botany, 89, 155-185.

Peterson, M. S. \& Meador, M. R. (1994). Effect of Salinity on Freshwater Fishes in Coastal Plain Drainage in the Southeastern U.S. Reviews in Fisheries sciences, 2(2), 95-121.

Quinn, G. P. \& Keough, M. J. (2002). Experimental Design and Data Analysis for Biologists. United Kingdom: Cam- 


\section{JURNAL BIDDJATI}

http://journal.uinsgd.ac.id/index.php/biodjati

bridge University Press.

Rahardjo, M. F., Sjafe'I, D. S., Affandi, R. \& Sulistiono, Hutabarat, J. (2011). Iktiology. Bandung (ID): Lubuk Agung.

Randall, J. E. \& Randall, H.A. (2001). Review of the Fishes of the Genus Kuhlia (Percifromes: Kuhliidae) on the Central Pacific. Pasific Sciences, 55(3), 227-256.

Rachmatika, I. (2003). Fish Fauna of The Gunung Halimun National Park, West Java. Jakarta: Biodiversity Conservation Project LIPI-JICA-PHKA.

Rachmatika I. \& Munim, A. (2005). Keanekaragaman Ikan di Beberapa Sungai Kabupaten Lebak dan Bogor. Bogor (ID): LIPI.

Robert, T. R. (1993). The Freshwater Fishes of Java, as Observed by Kuhl and van Hasselt in 1820-23. Zoologische Verhandelingen, 285, 1-92.

Salmin. (2005). Oksigen Terlarut (DO) dan Kebutuhan Oksigen Biologi (BOD) sebagai Salah Satu Indikator untuk Menentukan Kualitas Perairan. Oseana, 30(3), 21-26.

Shahnawaz, A., Venkateshwarlu, M., Somashekar, D. S. \& Santosh K. (2010). Fish diversity with relation to water quality of Bhadra River of Western Ghats (INDIA). Environmental Monitoring and Assessment, 161, 83-91.

Somerfield, P. J. (2008). Identification of the Bray-Curtis similarity index: Comment on Yoshioka Marine Ecology Progress Series, 72, 303-306.
Sulistiyarto, B., Soedharma, D., Rahardjo, M. F. \& Sumardjo. (2007). Pengaruh Musim Terhadap Komposisi Jenis dan Kemelimpahan Ikan di Rawa Lebak, Sungai Rungan, Palangkaraya, Kalimantan Tengah. Biodiversitas, 8(4), 270-273.

Tucker, C. S. \& D'Abramo, L. R. (2008). Managing High $p H$ in Freshwater Ponds. SRAC Publication No. 4604: Southern Regional Aquaculture Center.

Voris, H. K. (2000). Maps of Pleistocene sea Levels in Southeast Asia: Shorelines, river Systems and Time Durations. Journal of Biogeography, 27, 1153-1167.

Watanabe, M. (1972). First Record of the Gobioid Fish Rhyacicthys aspro from Formosa. Japanese Journal of Ichthyology, 19(2), 120-124.

Watson, R. E. (1991). A Provisional Review of the Genus Stenogobius with Description of a new Subgenus and Thirteen New Species (Pisces: Teleostei: Gobiidae). Records of the Western Australian Museum, 15(3), 627-710.

Yeager, L. A., Layman, C. A. \& Allgeier, J. E. (2011). Effects of Habitat Heterogeneity at Multiple Spatial Scales on Fish Community Assembly. Oecologia, 167, 157-168.

Yuningsih. (2012). Keracunan Sianida pada Hewan dan Upaya Pencegahannya Jurnal Litbang Pertanian, 31(1), 21-26 